\title{
TNF- $\alpha$-Activated MSC-CM Topical Gel Effective in Increasing PDGF LEVEL, Fibroblast Density, and Wound Healing Process Compared to Subcutaneous Injection Combination
}

\author{
Novalia Kuntardjo, ${ }^{1}$ Agung Putra, ${ }^{2,3,4}$ Edi Dharmana, ${ }^{2}$ Chodidjah, ${ }^{2}$ Taufiq R. Nasihun ${ }^{2}$ \\ ${ }^{1}$ Postgraduate Biomedical Program Faculty of Medicine Universitas Islam Sultan Agung, Semarang, Indonesia, \\ ${ }^{2}$ Department of Postgraduate Biomedical Science Faculty of Medicine Universitas Islam Sultan Agung, Semarang, \\ Indonesia, ${ }^{3}$ Stem Cell and Cancer Research Laboratory (SCCR) Faculty of Medicine, Univeritas Islam Sultan \\ Agung, Semarang, Indonesia, ${ }^{4}$ Department of Pathological Anatomy Faculty of Medicine \\ Universitas Islam Sultan Agung, Semarang, Indonesia
}

\begin{abstract}
Mesenchymal stem cells (MSCs) are multipotent stromal cells that have the capacity to regenerate tissue damage. However, they have several limitations. MSC-CM as a new approach treatment is widely used to solve the limitation of MSC in wound healing. The aim of this study was to evaluate the effectiveness of TNF- $\alpha$-activated MSC-CM topical gel compare to topical-subcutaneous injection combination on wound healing acceleration. This study was conducted between April-August 2018 at the Stem Cell and Cancer Research Laboratory (SCCR), Faculty of Medicine, Sultan Agung Islamic University, Semarang. Experimental post-test only control group design was performed by involving 36 animal models randomly divided into six groups; T1, T2 (MSC-CM in topical gel 100 $\mu \mathrm{L} ; 200 \mu \mathrm{L}$ ); ST1, ST2 (MSC-CM in subcutaneous injection: topical gel= $80 \mu \mathrm{L}: 20 \mu \mathrm{L} ; 160 \mu \mathrm{L}: 40 \mu \mathrm{L})$; CT (200 $\mu \mathrm{L}$ medium free TNF- $\alpha$ ); CST (PBS in subcutaneous injection: topical gel $=160 \mu \mathrm{L}: 40 \mu \mathrm{L}$ ). The measurement of PDGF level on day 3 and 6 was conducted using ELISA assay while the fibroblast density was analyzed by light microcopy. It was found that there was was a significant increase in PDGF and fibroblast density on day 6 in the topical group when compared to the combination group $(\mathrm{p}<0.05)$. It is concluded that the MSC-CM topical gel is more effective than combination of topical-subcutaneous injection.
\end{abstract}

Key words: Combination, fibroblast, MSC-CM, PDGF, subcutaneous MSC-CM, topical MSC-CM

\section{MSC-CM Topikal yang diaktivasi TNF- $\alpha$ Efektif dalam Peningkatan Level PDGF, Densitas Fibroblast, dan Mempercepat Penyembuhan Luka dibanding dengan Kombinasi Injeksi Subkutan}

\begin{abstract}
Abstrak
Mesenchymal stem cells (MSCs) merupakan sel stroma multipoten yang memiliki kemampuan untuk meregenerasi kerusakan jaringan. Namun, MSC memiliki beberapa keterbatasan. MSC-CM sebagai terapi pendekatan baru digunakan untuk mengatasi keterbatasan MSC dalam penyembuhan luka. Tujuan penelitian ini adalah menilai efektivitas MSC-CM topikal yang diaktvasi TNF- $\alpha$ dibanding dengan kombinasi topikal-injeksi subkutan pada percepatan penyembuhan luka. Penelitian ini dilaksanakan pada bulan April-Agustus 2018 di Laboratorium Stem Cell and Cancer Research (SCCR), Fakultas Kedokteran, Universitas Islam Sultan Agung, Semarang. Penelitian menggunakan eksperimen laboratorium dengan rancangan post-test only control group, menggunakan 36 tikus galur wistar yang dibagi secara acak menjadi 6 kelompok; T1, T2 (MSC-CM gel topikal $100 \mu \mathrm{L} ; 200 \mu \mathrm{L}$ ); ST1, ST2 (MSC-CM injeksi subkutan: gel topikal= $80 \mu \mathrm{L}: 20 \mu \mathrm{L} ; 160 \mu \mathrm{L}: 40 \mu \mathrm{L}$ ); CT (200 $\mu \mathrm{L}$ medium tanpa TNF- $\alpha$ ); CST (PBS injeksi subkutan : gel topikal= $160 \mu \mathrm{L}: 40 \mu \mathrm{L}$ ). Pengukuran kadar PDGF pada hari ke- 3 dan ke- 6 mengunakan ELISA, sedangkan jumlah fibroblas dilihat mengunakan mikroskop cahaya. Hasil penelitian ini menunjukkan peningkatan kadar PDGF dan jumlah fibroblas yang signifikan di hari ke-6 pada MSC-CM gel topical dibanding dengan kombinasi topical-injeksi subukutan $(\mathrm{p}<0,05)$. Simpulan penelitian ini adalah pemberian MSC-CM secara topikal lebih efektif dibanding dengan kombinasi topikal-injeksi subkutan.
\end{abstract}

Kata kunci: Konditional medium, MSC-CM topikal, MSC-CM kombinasi, PDGF, Fibroblas

Corresponding Author: Agung Putra, Department of Postgraduate Biomedical Science Faculty of Medicine Universitas Islam Sultan Agung Semarang. Candi Prambanan Utara Raya Kav. 1135-1136 Kelurahan Kalipancur, Manyaran, Kecamatan Ngaliyan, Semarang, Central Java, 50112 Indonesia, Email: dr.agungptr@gmail.com 


\section{Introduction}

Mesenchymal stem cells (MSCs) are defined as multipotent stromal cells that have a capacity to regulate the inflammatory response and regenerate tissue damage. ${ }^{1-3}$ They may be isolated from umbilical cord, bone marrow, and adipose. Based on International Society for Cellular Therapy (ISCT), MSCs have criteria: adherence to plastic culture under standard medium conditions; may express CD90, CD73, CD105, and lack of CD14, CD45, CD34, CD11b, CD31 and HLA-DR expression; may differentiate into osteocytes, chondrocytes, and adipocytes. ${ }^{4}$ Umbilical cord-mesenchymal stem cells (UCMSCs) becomes an alternative source of MSCs because they can be noninvasively collected and expanded, even cryopreserved. ${ }^{5}$ However, MSCs have several limitations such as complexity technique and low survivability of cells after being transplanted in a target area. Therefore, developing an alternative approach is needed such as using soluble molecules released by MSCs.

Previous studies reported that MSCs under inflammation produce several anti-inflammatory cytokines such as IL-10 and TGF- $\beta$ in addition to molecule proliferation, particularly plateletderived growth factor (PDGF), and vascular endothelia growth factor (VEGF) into medium culture known as MSC-conditioned medium (MSC-CM). ${ }^{6,7}$ TNF- $\alpha$-activated MSCs may secrete large quantities of soluble molecule for accelerating the regeneration of tissue damage. ${ }^{8}$ Platelet-derived growth factor is one of several growth factors which can control the growth, differentiation, and activation of diverse cell types by stimulating chemotaxis, angiogenesis, and fibroblasts proliferation. ${ }^{9-11}$ These facts suggest that the soluble molecule secreted by MSCs as CM might be one of effective ways in wound healing treatment.

Mesenchymal Stem Cell Conditioned Media (MSC-CM) has been widely used to accelerate wound healing. From several studies, it was reported that the use of MSC-CM topical is effective. Previous study reported that MSCCM topical contains IL-8 that increase the accumulation of macrophage, stimulates angiogenesis, and increases cell proliferation by topical application on cutaneous wound healing. (12) Mesenchymal Stem Cell Conditioned Media (MSC-CM) applied by subcutaneous injection may accelerate wound healing..$^{13}$ In other side, topical- subcutaneous injection combination can enhance macrophage migration, keratinocytes, and endothelial cell. ${ }^{14}$ These facts show that MSC-CM is effective to enhance wound healing. However, the best technique to accelerate wound healing remains unclear. The aim of this study was to evaluate the effectiveness of MSC-CM topical gel compared to topical-subcutaneous injection combination on wound healing acceleration.

\section{Methods}

This study was conducted from April to August 2018 in Stem Cell and Cancer Research Laboratory (SCCR), Faculty of Medicine, Sultan Agung Islamic University, Semarang. All activities were approved and in accordance with the Bioethics Commission (Komisi Bioetik), Faculty of Medicine, Universitas Islam Sultan Agung, Semarang No. 158/III/2017/Komisi Bioetik.

The isolation of MSCs from umbilical cord of 19 days pregnancy of female rat was performed. After the umbilicus was washed using PBS, the blood vessels were removed then cut into lengths of 2-5 mm using a sterile scalpel. The sections were then distributed evenly on T25 flask. The medium used was Dulbecco's modified Eagle's medium (DMEM) (Sigma-Aldrich, St. Louis, MO) supplemented with $10 \%$ PBS, $100 \mathrm{IU} / \mathrm{ml}$ penicillin/streptomycin (GIBCO, Invitrogen), then incubated at $37{ }^{\circ} \mathrm{C}$ with $5 \% \mathrm{CO}_{2}$. The medium was refreshed every 3 days.

The analysis of MSCs-like surface antigens wasperfomed by flow cytometric analysis at the fourth passage. The cells were subsequently incubated in the dark with fluorescein isothiocyanate (FITC)-conjugated, allophycocyanin (APC)-conjugated, or phycoerythrin (PE)-conjugated monoclonal antibodies, including CD105, CD90, and CD73. FITC-, APC-, and PE-conjugated isotypes were used as negative controls. The analysis was performed using BD Pharmingen ${ }^{\mathrm{TM}}$ (BD Bioscience, Franklin Lakes, NJ, USA) at $4{ }^{\circ} \mathrm{C}$ for 30 minutes. The cells were washed twice with $1 \%$ BSA/PBS, resuspended in $200 \mu \mathrm{L} 1 \%$ BSA/ PBS, and analyzed by a flow cytometer (BD Biosciences, San Jose, CA, USA).

The MSCs were grown in plate at densities of $1 \times 10^{4}$ cells/well cultured in DMEM supplemented with osteogenic induction medium containing $10 \mathrm{mmol} / \mathrm{L} \beta$-glycerophosphate, $10^{-7} \mathrm{~mol} / \mathrm{L} / 0.1$ $\mu \mathrm{M}$ dexamethasone, $50 \mu \mathrm{mol} / \mathrm{L}$ ascorbate-2phosphate (Sigma-Aldrich, Louis St, MO), and $10 \%$ fetal bovine serum (FBS). To find calcium deposits, the cells were rinsed in PBS and fixed with cold $70 \%$ ethanol $(\mathrm{v} / \mathrm{v})$ for 1 hour at room 
temperature, then rinsed three times with double distilled water. The osteogenic differentiation was analyzed by Alizarin Red staining by added 1 mL 2\% Alizarin Red solution (w/v) (pH 4.1-4.3) to the cells, incubated for 30 minutes at room temperature, then rinsed four times in double distilled water.

The MSCs $\left(1 \times 10^{4}\right.$ cells/well) were cultured in DMEM medium (Sigma-Aldrich, Louis St, MO), supplemented with $10 \mathrm{ng} / \mathrm{mL}$ recombinant TNF- $\alpha$ (BioLegend, San Diego, CA) on a 24-well plate. The cells were then incubated for 24 hours at $37{ }^{\circ} \mathrm{C}$ with $5 \% \mathrm{CO}_{2}$. After 24 hour incubation, MSC-CM was collected by centrifuging the cells at 2,000 rpm for 7 minutes to remove cell debris. In addition, for vehicle group, the DMEM serum-free medium was similarly processed. Conditional medium gel was made by supplemented base gel with the conditional medium.

Experimental post-test only control groups design was performed involving 36 animals model male Wistar rat weighted $250 \mathrm{~g}$ that were housed at a constant temperature $\left(22 \pm 2^{\circ} \mathrm{C}\right)$ and $60 \%$ relative humidity, with 12:12-hour light-dark cycle. The rats were anesthetized by isofluorane inhalation, then the dorsal hair was shaved and cleaned with tincture of iodine. One full-thickness circular $6 \mathrm{~mm}$ biopsy punch excision was done for each rat. The animals were randomly divided into six groups; $\mathrm{T} 1, \mathrm{~T} 2$ (MSC-CM in topical gel $100 \mu \mathrm{L} ; 200 \mu \mathrm{L}$ ); ST1, ST2 (MSC-CM in subcutaneous injection: topical gel = $80 \mu \mathrm{L}: 20 \mu \mathrm{L} ; 160 \mu \mathrm{L}: 40 \mu \mathrm{L}) ; \mathrm{CT}(200 \mu \mathrm{L}$ medium free TNF- $\alpha$ ); CST (PBS in subcutaneous injection : topical gel $=160 \mu \mathrm{L}: 40 \mu \mathrm{L}$ ). The measurement of PDGF levels on day 3 and 6 using ELISA assay was performed while the fibroblast density was analyzed by light microcopy.

In vivo analysis was done using rat's serum sample to check PDGF levels. Platelet derived growth factor (PDGF) assay by means of an ELISA kit was performed at room temperature according to the manufacturer's instructions (Fine Test, Wuhan, China). The serum was measured in day 3 and day 6 according to a standard curve constructed for each assay. The colorimetric absorbance as the PDGF concentrations $(\mathrm{pg} / \mathrm{mL})$ was analyzed at a wavelength of $450 \mathrm{~nm}$ using a microplate reader on day 3 and 6 of the experiment.

The wounded tissues were fixed in formalin then blocked in paraffin. Horizontal sections were taken from each paraffin block using microtome. Hematoxylin and eosin (H-E) staining was performed by dissolving the paraffin substances first with Xylene for 1 minute. Hereinafter, each group of fibroblast was evaluated by pathologist.

The comparison that was more than two groups used ANOVA, followed by Post Hoc Fisher's LSD. A $P$ value of $<0.05$ was considered significant. All analysis was performed with SPSS 16.0.

\section{Results}

The characteristics of MSCs after flow cytometry analysis were shown in figure 1 . The cells were cultured for 3-4 passages before used for this study. The MSCs positively expressed $99.2 \%$ of CD73, 96,7\% of CD 90 , and $67,1 \%$ of CD105. The purified cells showed fusiform appearance and became $80 \%$ confluent after 5-7 days in culture and were regularly passaged.

After 21 day incubation with osteogenicdifferentiating medium, the MSCs were stained with Alizarin Red staining to analyze osteogenic differentiation. The MSCs were able to be
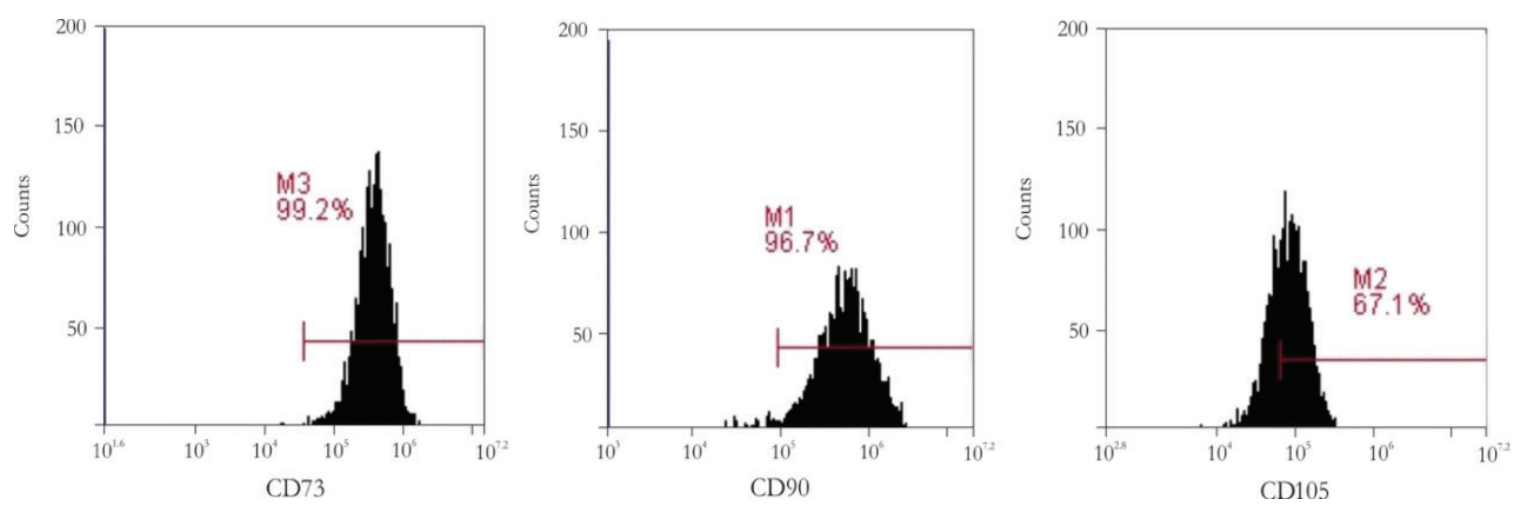

Figure 1 Flow Cytometry Analysis of MSCs Positive Markers. The Characteristic of UC-MSCs Expressed CD73, CD90, and CD105 
N. Kuntardjo, et al: TNF- $\alpha$-Activated MSC-CM Topical Gel Effective in Increasing PDGF LEVEL, Fibroblast Density, and Wound Healing Process Compared to Subcutaneous Injection Combination

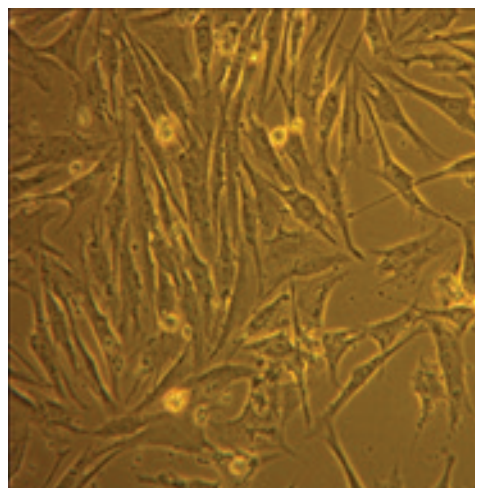

a

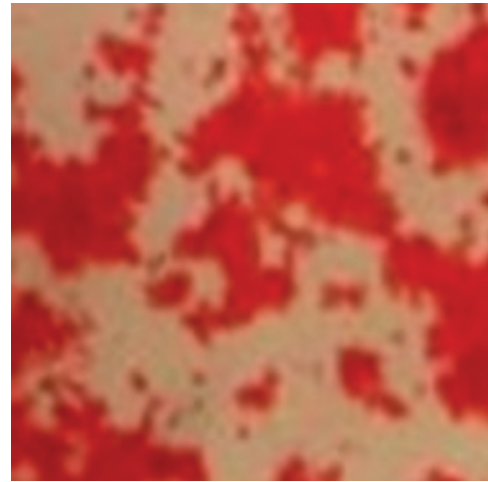

b

Figure 2 (a) The Morphology of UC-MSC-Like From the In Vitro Culture Showed Polygonal Shape and Fibroblast-Like Cells, with 40x Magnification, (b) The Osteogenic Differentiation with Alizarin Red Staining Appears Red Color in MSCs
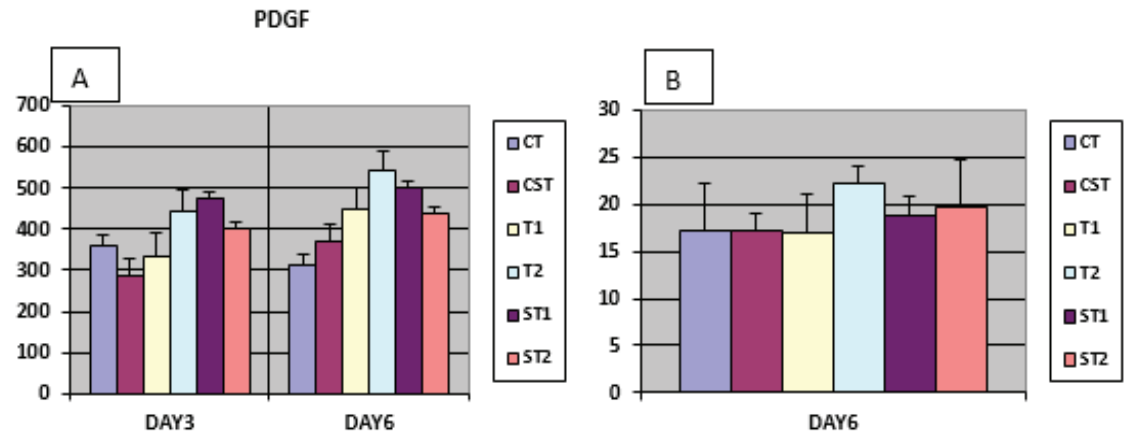

Figure 3 Effects of MSC-CM Activated TNF- $\alpha$ on PDGF Level and Fibroblast Density (A) PDGF Levels on Day 3 and 6 (B) Fibroblast Density on Day 6. (CT $=200 \mu \mathrm{L}$ Medium Free TNF- $\alpha$; CST $=$ $160 \mu \mathrm{L}$ Subcutaneous Injection, $40 \mu \mathrm{L}$ Topical Gel PBS; T1= 100 $\mu \mathrm{L}$ MSC-CM Topical Gel; T2 $=200 \mu \mathrm{L}$ MSC-CM Topical Gel; ST1 $=80 \mu \mathrm{L}$ Subcutaneous Injection, $20 \mu \mathrm{L}$ Topical Gel MSC-CM; ST2= $160 \mu \mathrm{L}$ Subcutaneous Injection, $40 \mu \mathrm{L}$ Topical Gel MSC-CM)

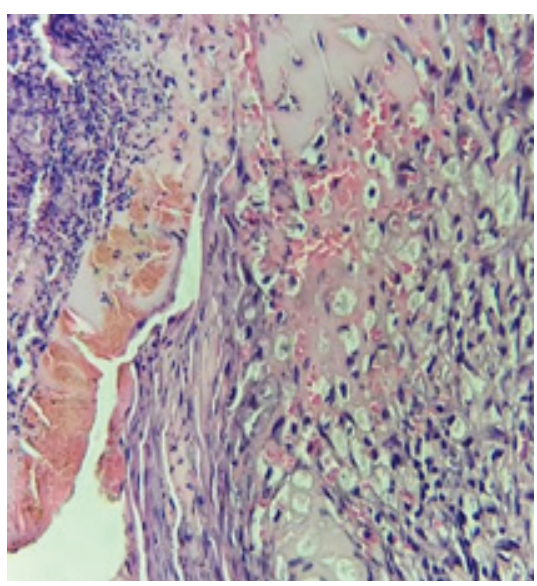

A

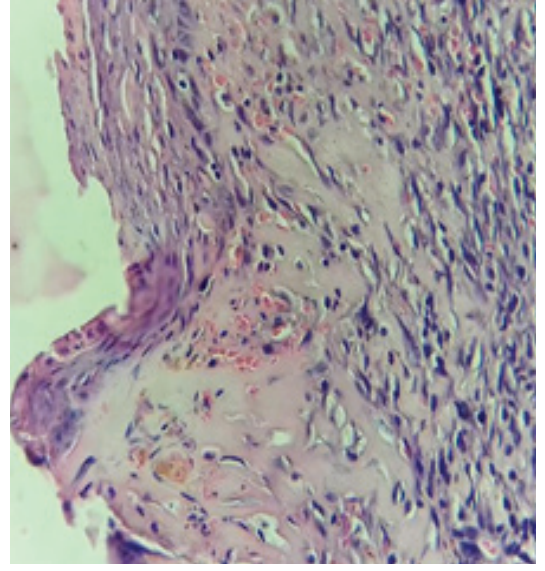

B

Figure 4. The Histological Appearance of Fibroblast. (A) Fibroblast Day 3 and (B) Fibroblast Day 6 
N. Kuntardjo, et al: TNF- $\alpha$-Activated MSC-CM Topical Gel Effective in Increasing PDGF LEVEL, Fibroblast Density, and Wound Healing Process Compared to Subcutaneous Injection Combination

differentiated into osteogenic cells indicated by a red color from Alizarin red staining (Figure $2 \mathrm{~b}$ ).

The level of PDGF was measured using ELISA with blood sample taken from ophthalmic vein of rats, and then the fibroblast was measured using HE staining. There were significant differences between topical gel group compared to topicalsubcutaneous injection combination in PDGF levels and fibroblast density on day $6(\mathrm{p}<0.05)$. The best PDGF levels and fibroblast density were found on day 6 in T2 group $542.42 \pm 4.15 \mathrm{pg} / \mathrm{mL}$ and $22.2 \pm 0.83 \times 10^{5}$ cell $/ \mathrm{mL}$ respectively.. There was no significant difference of PDGF levels on day 3 between topical gel (T2) and topicalsubcutaneous injection combination group (ST1) (Figure 3). These results were supported with the appearance of fibroblast analysis using light microscope.

\section{Discussion}

Cutaneous non-healing wounds have been a subject of concern to the medical problem. Previous study reported that MSC-CM has been widely used to accelerate wound healing by topical application that has been reported effective. ${ }^{13,14}$ In other study, it was demonstrated that the topical-subcutaneous injection combination may accelerate wound healing, however the subcutaneous injection is an invasive technique. These facts show that subcutaneous injection and topical are the effective techniques of MSC-CM application for accelerating wound healing. Nonetheless, the effectiveness of both techniques remains unclear. In this study, we used full-thickness wound animal model, then compared the effectiveness of topical gel to topical-subcutaneous injection combination using TNF- $\alpha$ activated MSC-CM like previous study. ${ }^{13,14}$

Theresult of the study showed that there was a significant increase in PDGF on day 6 in topical compared to combination group. We suggest that the wound healing process was accelerated to the proliferation stage in topical gel group. Meanwhile, the combination group remained in inflammatory process due to invasive subcutaneous injection. On the other hand, there was no significant increase between topical and combination group on day 3 due to the wound healing process that was still in inflammation stage. The soluble molecule inside the MSCCM such as interleukin-10 (IL-10), TGF-b may inhibit inflammation process leading to the shift of inflammation to proliferation stage marked by the increase of PDGF levels. ${ }^{15}$ These are in line with previous study reporting that the PDGF may activate and induce cell proliferation particularly fibroblast by up-regulating ERK pathway. ${ }^{16,17}$

The activated fibroblast correlates with wound healing as found in our study at Figure 4. There was a significant increase in fibroblast density on day 6 in topical compared to combination group. These facts showed that the wound healing process accelerated the shift of inflammation to the proliferation stage at topical to combination group. There was an ongoing inflammation process on combination group as a result of invasive subcutaneous injection, whereas the proliferation stage was gradually running on topical group. This is in accordance with previous study reporting that there are migration and completely covered spaces of wound at scratch wound assays post CM exposure. ${ }^{18}$ This is in line with another study reporting that MSC-CM accelerates wound closure by stimulating the increase of fibroblast and keratinocyte cells migration, rather than on cell proliferation or survival. ${ }^{19}$

The expression of PDGF initiates the activity of fibroblast by up-regulating ERK1/2 pathway, which induces the activation of MAPK leading to the expression of c-Fos protein and the transcription of various growth factors, particularly for regeneration cause in wound closure. ${ }^{16}$

The conclusion is that the MSC-CM topical gel is more effective than topical-subcutaneous injection combination. The limitation of this study was the soluble molecule inside the MSC$\mathrm{CM}$ and fibroblast in remodeling phase were not measured.

\section{Acknowledgment}

We would like to thank Stem Cell and Cancer Research Laboratory, Medical Faculty, Universitas Islam Sultan Agung Semarang and Department of Postgraduate Biomedical Science Medical Faculty, Universitas Islam Sultan Agung Semarang for all facilities provided to finish this study.

\section{References}

1. Prockop DJ, Youn OJ. Mesenchymal stem/ stromal cells (MSCs): role as guardians of inflammation. Mol Ther. 2012;20(1):14-20.

2. Pang C, Ibrahim A, Bulstrode NW, Ferretti 
P. An overview of the therapeutic potential of regenerative medicine in cutaneous wound healing: advances and limitations in regenerative medicine for stimulating wound repair. Int Wound J. 2017;14(3):450-9.

3. Chen X, Wang S, Cao W. Mesenchymal stem cell-mediated immunomodulation in cell therapy of neurodegenerative diseases. Cell Immunol. 2018;326:8-14.

4. Tsai HW, Wang PH, Tsui KH. Mesenchymal stem cell in wound healing and regeneration. J Chinese Med Assoc. 2018;81(3):223-34.

5. Klinker MW. Mesenchymal stem cells in the treatment of inflammatory and autoimmune diseases in experimental animal models. World J Stem Cells. 2015;7(3):556.

6. Putra A, Ridwan F, Putridewi A, Kustiyah A, Wirastuti K, Sadyah NA, etal. The role of TNF- $\alpha$ induced MSCs on suppressive inflammation by increasing TGF- $\beta$ and IL-10. Open Access Maced J Med Sci. 2018;6(10):1779-83.

7. Ho CH, Lan CW, Liao CY, Hung SC, Li HY, Sung YJ. Mesenchymal stem cells and their conditioned medium can enhance the repair of uterine defects in a rat model. J Chinese Med Assoc. 2018;81(3):268-76.

8. Meiliana A, Dewi NM, Wijaya A. Mesenchymal stem cells manage endogenous tissue regeneration. Indonesian Biomed J. 2011; 8(2):71-90.

9. Andrae J, Gallini R, and Betsholtz C. Role of platelet-derived growth factors in physiology and medicine. Genes Dev. 2008;22:1276312.

10. Raica M, Cimpean AM. Platelet-derived growth factor (PDGF)/PDGF receptors (PDGFR) axis as target for antitumor and antiangiogenic therapy. Pharmaceuticals. 2010;3:572-99

11. Zhao J, Hu L, Liu J, Gong N, Chen L. The effects of cytokines in adipose stem cell-conditioned medium on the migration and proliferation of skin fibroblasts in vitro. Biomed Res Int.
2013;2013:578479.

12. Kwon YW, Heo SC, Jeong GO, Yoon JW, Mo WM, Lee MJ, et al. Tumor necrosis factor- $\alpha-$ activated mesenchymal stem cells promote endothelial progenitor cell homing and angiogenesis. Biochim Biophys Acta-Mol Basis Dis. 2013;1832(12):2136-44,

13. Lee MJ, Kim J, Lee K Il, Shin JM, Chae J Il, Chung HM. Enhancement of wound healing by secretory factors of endothelial precursor cells derived from human embryonic stem cells. Cytotherapy. 2011;13(2):165-78.

14. Chen L, Tredget EE, Wu PY, Wu Y. Paracrine factors of mesenchymal stem cells recruit macrophages and endothelial lineage cells and enhance wound healing. PLoS One. 2008;3(4):e1886.

15. Haque N, Abu KNH, Rahman MT. Optimization of pre-transplantation conditions to enhance the efficacy of mesenchymal stem cells. Int J Biol Sci. 2015;11(3):324-34.

16. Choi JW, Kim S, Kim TM, Kim YM, Seo HW, Park TS, et al. Basic fibroblast growth factor activates MEK/ERK Cell signaling pathway and stimulates the proliferation of chicken primordial germ cells. PLoS One. 2010;5(9):e12968.

17. Deng $X$, Jin K, Li Y, Gu W, Liu M, Zhou L. Platelet-Derived growth factor and transforming growth factor $\beta 1$ regulate ARDS-Associated lung fibrosis through distinct signaling pathways. Cell Physiol Biochem. 2015;36(3):937-46.

18. Fong GH. Mechanisms of adaptive angiogenesis to tissue hypoxia. Angiogenesis. 2008;11(2):121-40.

19. Chen J, Li Y, Hao H, Li C, Du Y, Hu Y, et al. Mesenchymal stem cell conditioned medium promotes proliferation and migration of alveolar epithelial cells under septic conditions in vitro via the JNK-P38 signaling pathway. Cell Physiol Biochem. 2015;37(5):1830-46. 